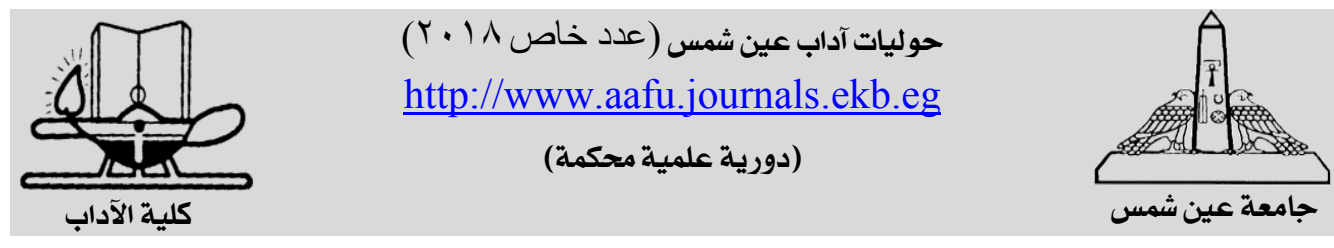

\title{
التقديم والتأخير في أسلوب النداء التوائ دراسة في الدلالة التركيبية في أحاديث السنن الأربعة
}

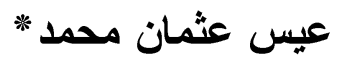

ماجستير في اللغة العربية - نحو وصرف - جامعة عمر المختار

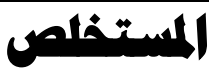

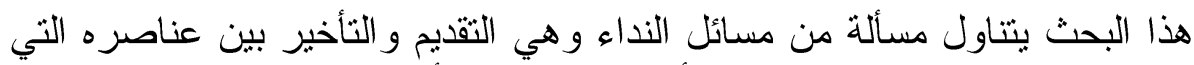

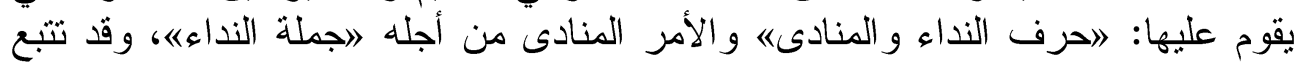

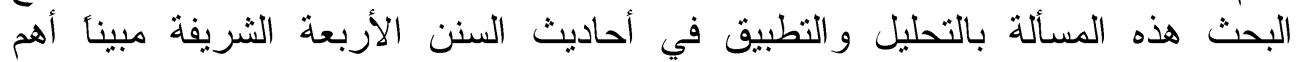

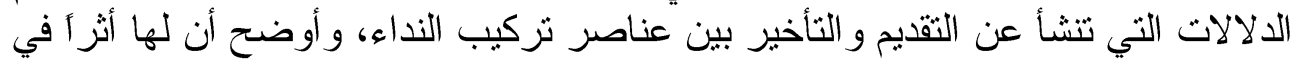
المعنى الدلالي في تركيب الجملة. 
عالج النحويون النداء معالجة شاملة، شملت كل جو انبه، ابتداء من تعريفه، وذكر

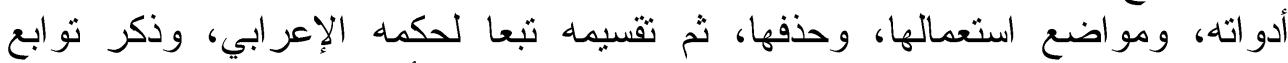

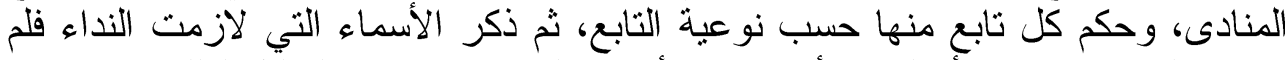

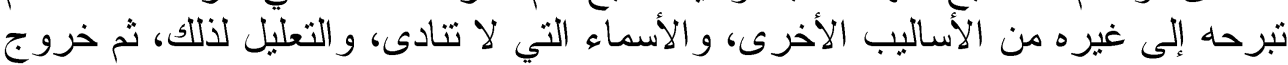

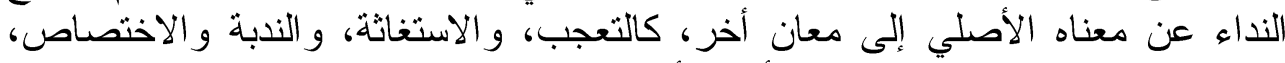

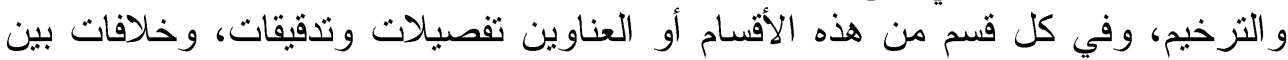

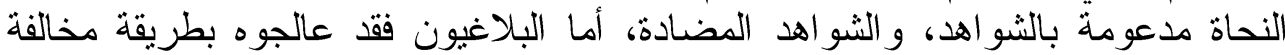

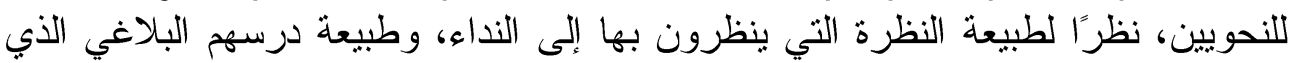

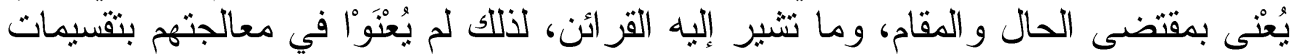

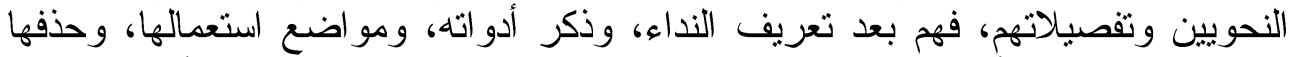

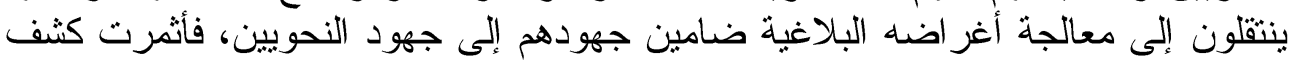

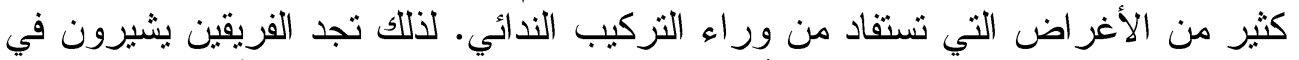

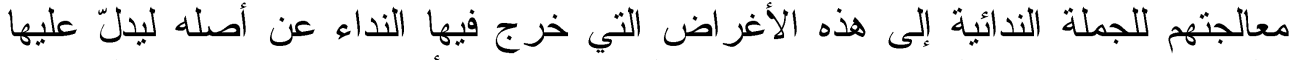

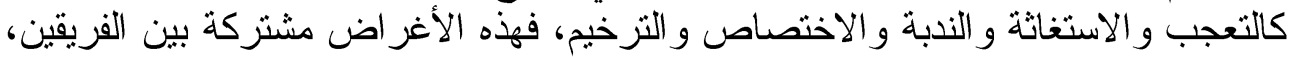

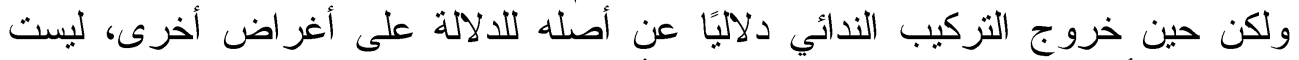

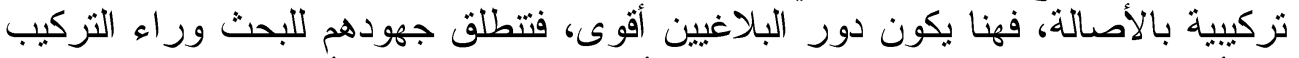

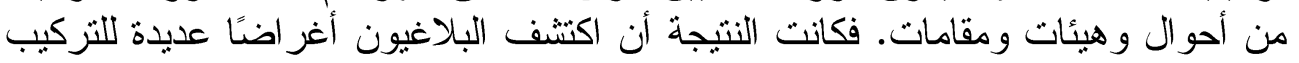

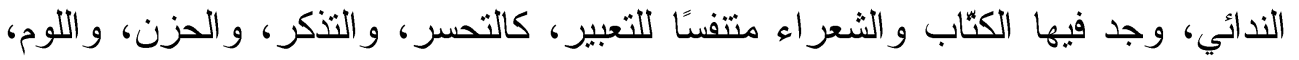

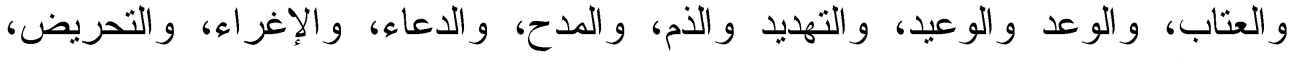

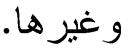
إذن الغرض البلاغي للتركيب الندائي يتحدد من خلال العلاقة التي نتشأ بين المنادي

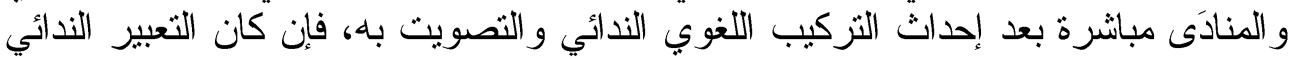

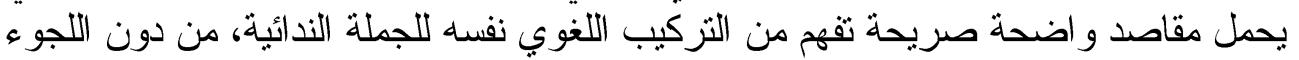

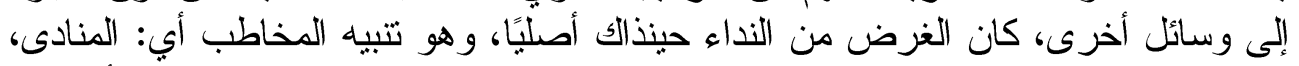

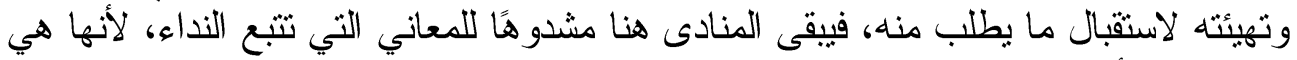

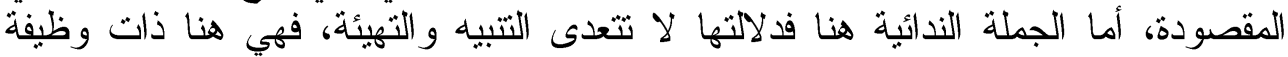

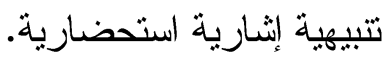
إما إن كان التركيب الندائي خارجا عن الأصل بتأخير جملة النداء أو توسطها

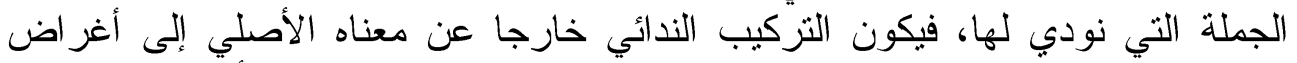

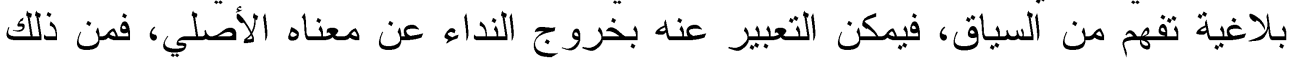

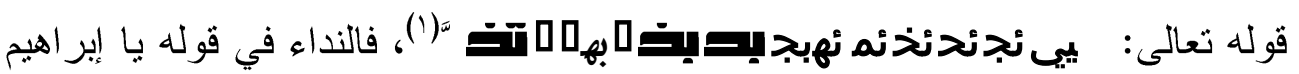

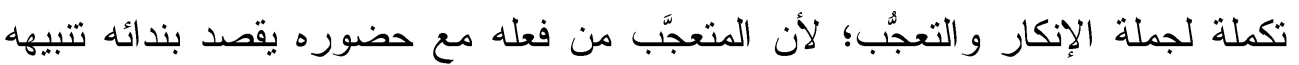

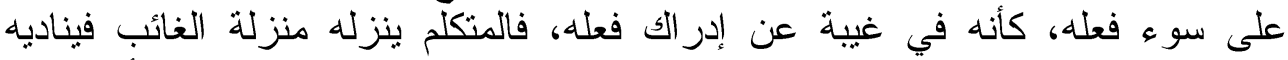

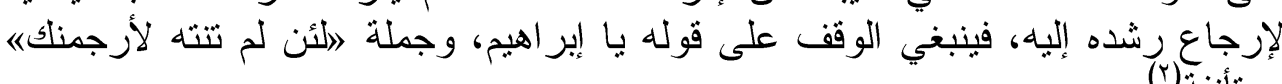
مستأنفة (r)

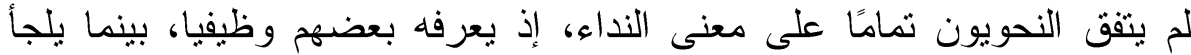
آخرون إلى تعريفه انطلافًا من أحو اله الإعرابية، و التعريف الذي يمكن إيثاره؛ لجمعه بين لئن 
الأمرين، هو ما أورده ابن عقيل، حيث قال: 》هو طلب المتكلم إقبال المخاطب بو اسطة

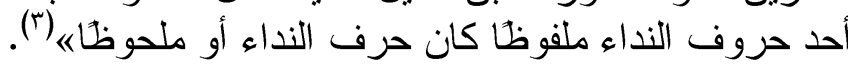

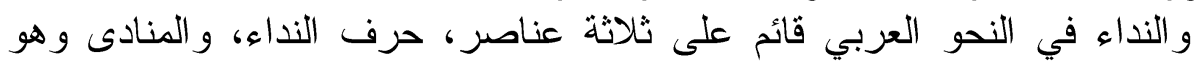

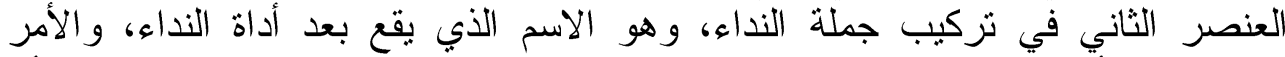

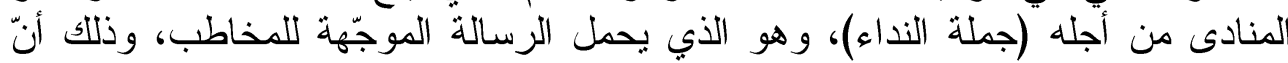

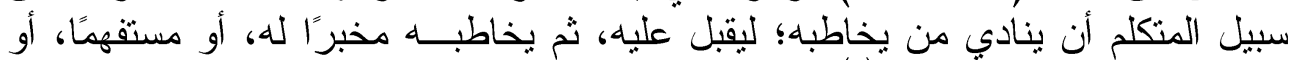

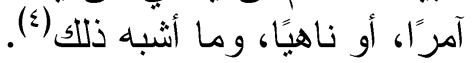

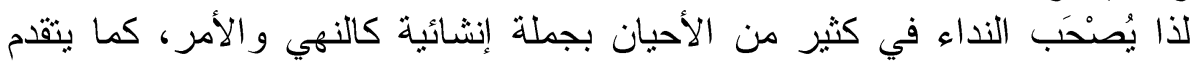

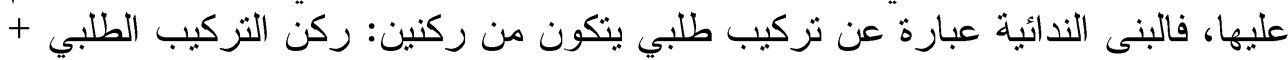

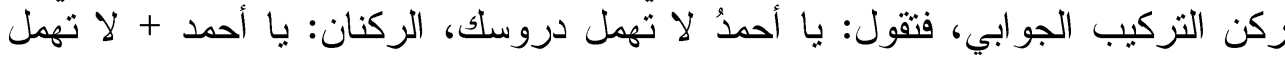

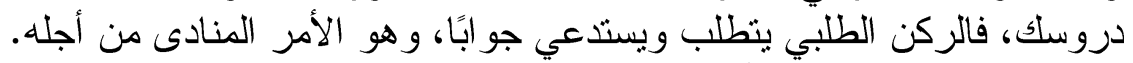

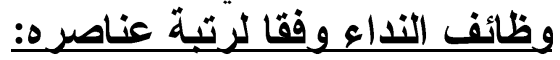

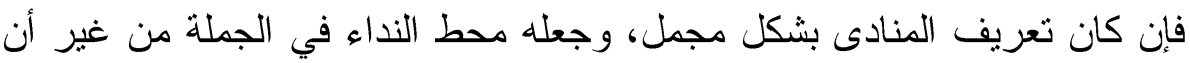

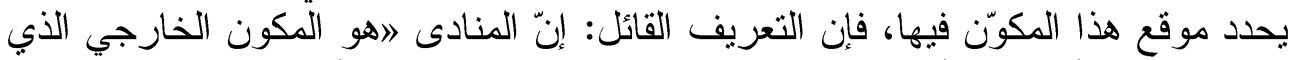

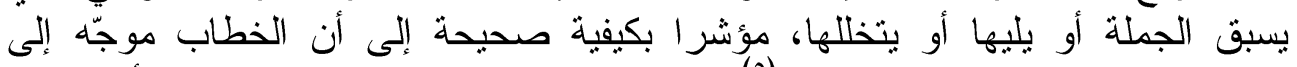

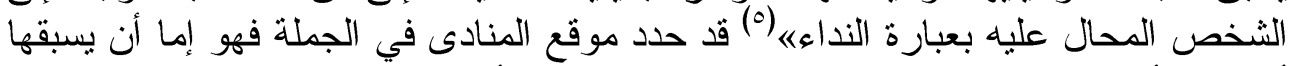

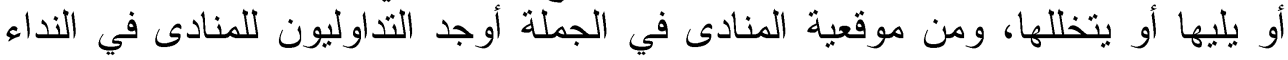

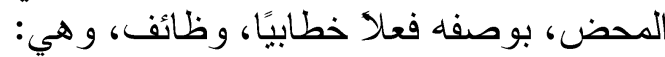
الاستر عاء و هذه الوظيفة تتحقق عندما يستهل المتكلم الخطاب بالنداء المحض، فإنه

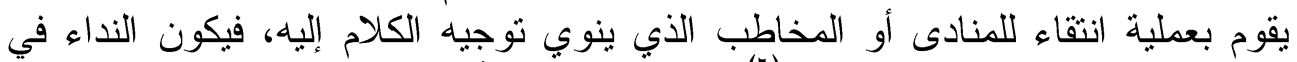

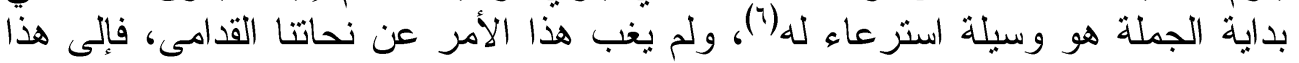

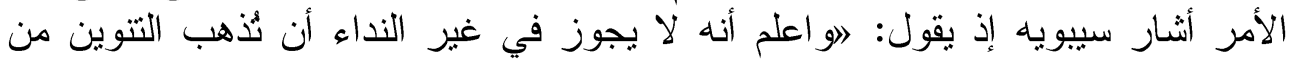

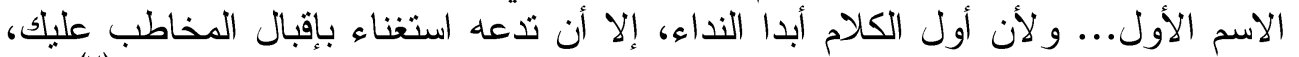

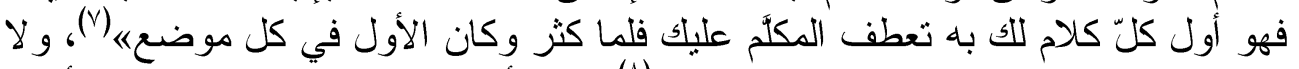

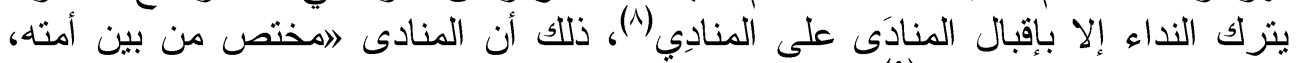

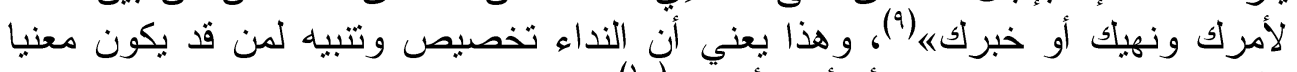

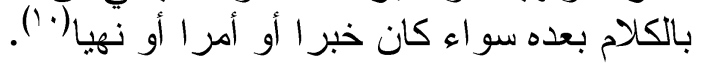
- الحفظ و التعبين، وهي الوظيفة الثانية للنداء، وتتحقق هذه الوظبفة التهي حينما يورد المتكلم

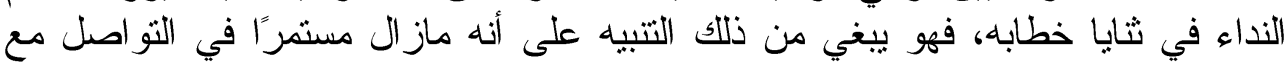

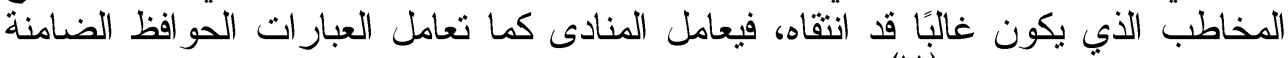

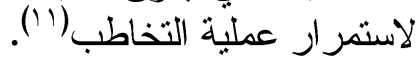

- التخصيص و التصحيح، وتتحقق عندما يأتي المنادى بعد ثمام الخطاب؛ لأنه يريد

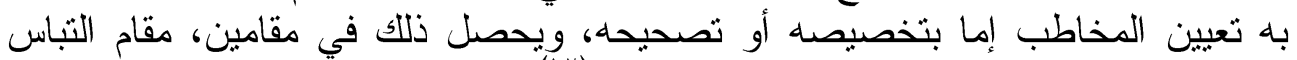

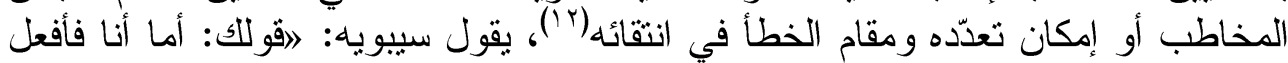

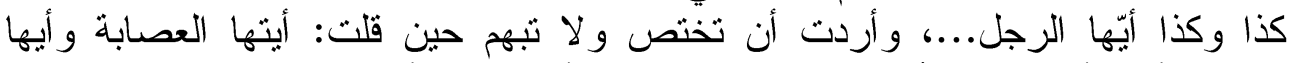

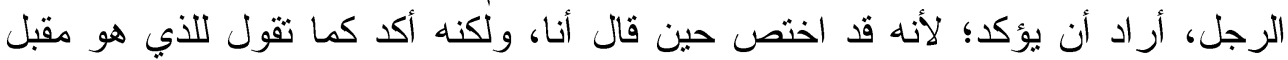

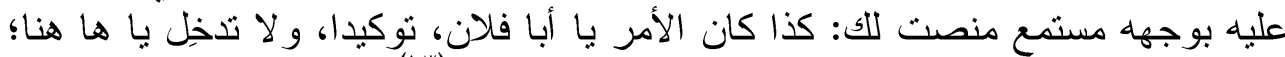

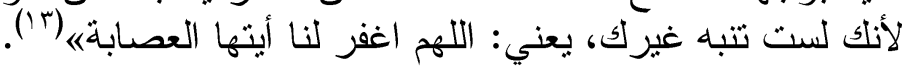

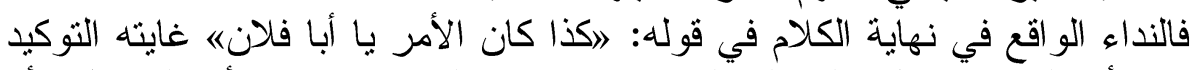

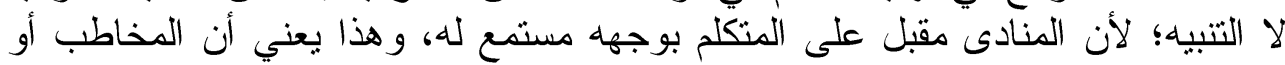


المنادى قد تم تعيينه وتحديده مسبقا، فهو لبس بحاجة إلى التتبيه ولكن بحاجة إلى توكيد هذا التعبين.

إذن بمكن القول إنّ تزكيب النداء - وفق ما وضحنا- يكون نحو المعادلة التالية: النــداء = (حرف النداء + المنادى) + جملة الغرض من النداء (الأمر، الاستقهام، النهي،

و الغالب في نركيب النداء - إن لم يكن الأصل - أن يتقدم جملة النداء التي تتكون من حرف النداء و المنادى، وهما متلازمان لا يفصل بينهما في سعة الكلام، بل على القلة

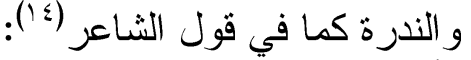

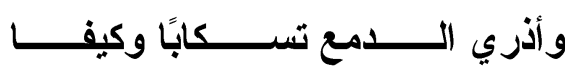

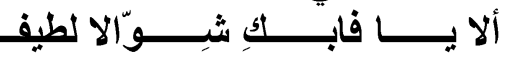
أي: يا لطبفة، فرخمت وفصلت بفعل الأمر وما عداه من عناصر الجملة، ولكن قد يثأخر

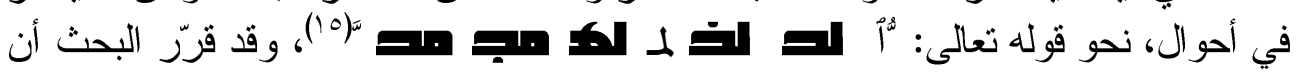

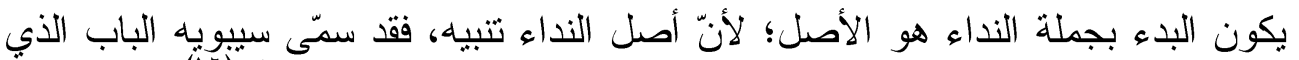

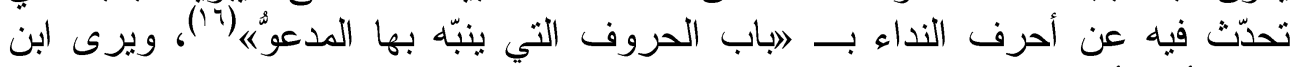
يعيش أن 》أصل النداء تتبيه المدعوّ؛ ليقبل عليك، وتؤثر في الندبة والاستغاثة و التعجب،

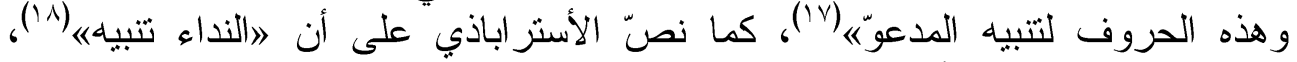

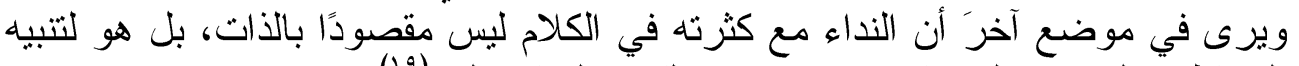

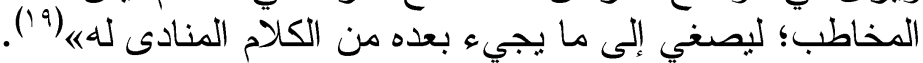

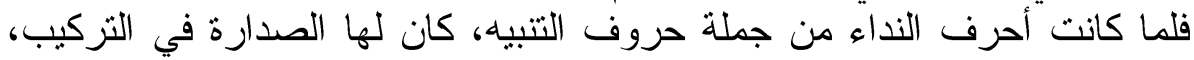

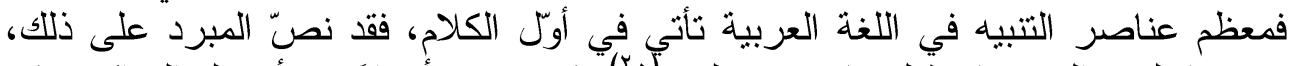

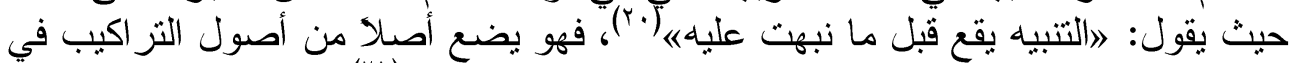

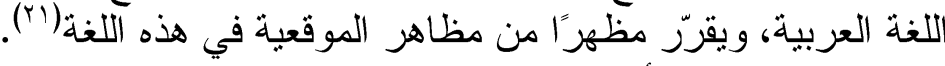

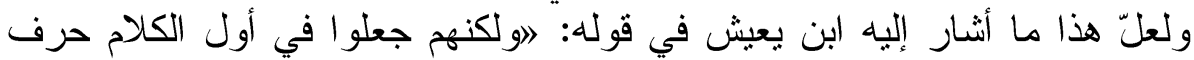

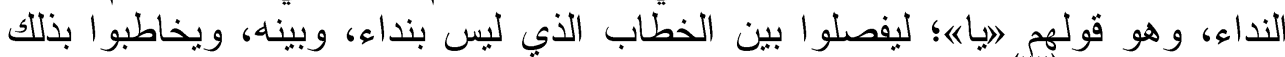

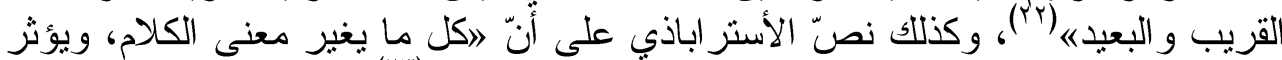

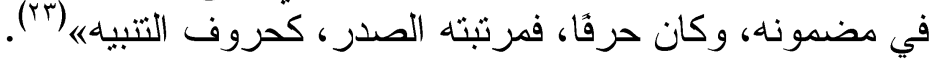

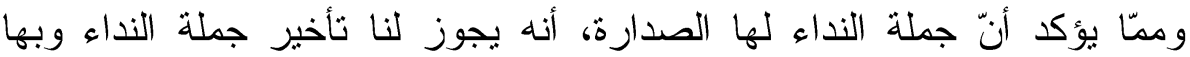

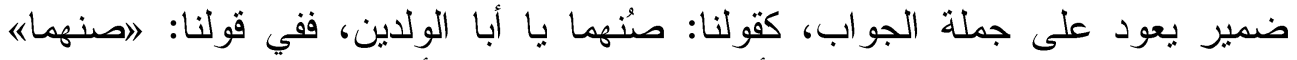

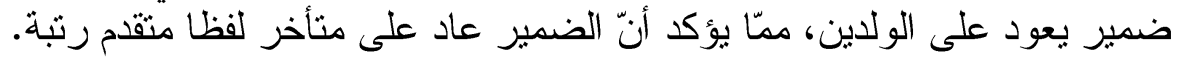

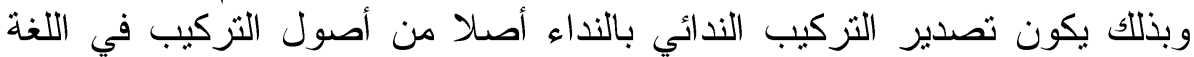

العربية، ومظهرًا من مظاهر الموقعية فيها.

التقديم والتأخير في تركيب التداء فن في أحاديث السنن الأربعة:

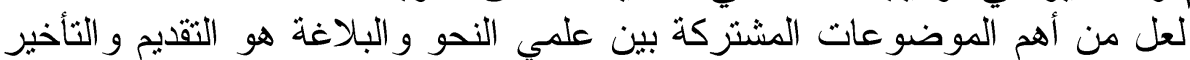

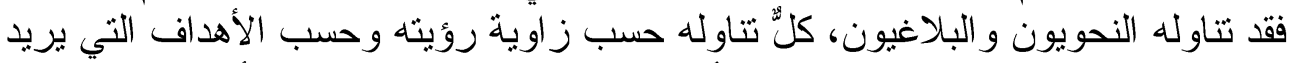

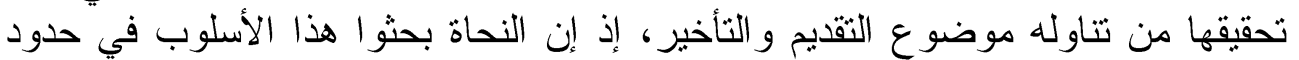

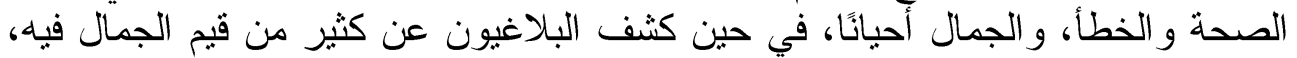

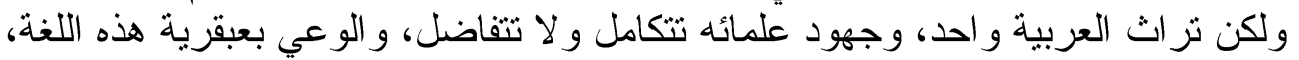

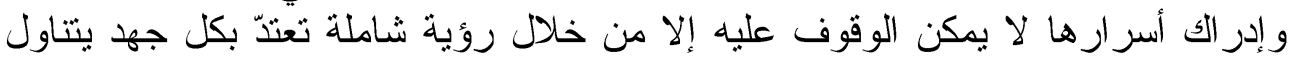


و هذا عرض للأحاديث التي جاءت وجملة النداء في بدابة التركيب، مكتفين بأمثلة

قليلة تبين، دلالة تقديم جملة النداء في أول التركيب؛ لكون هذا هو الأصل إذا ما فا عددنا النداء من أدو ات التنبيه، التي لها الصدارة في التركيب، ثم نعرض للأحاديث التي خالفت هـ الته

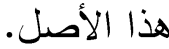

عن بشير ابن الخصاصيّة، أنّ رسول الله e، رأى رجلا يمشي بين المقابر في

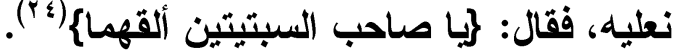

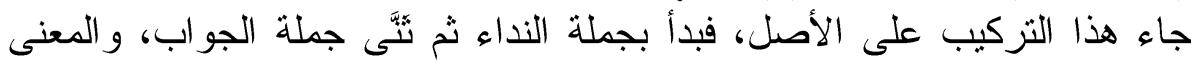
ليس خاصا بالسبتيتين، بل هو عام في جميع النعال، وبدأ بالنداء المضاف إلى التى السبتيتين،

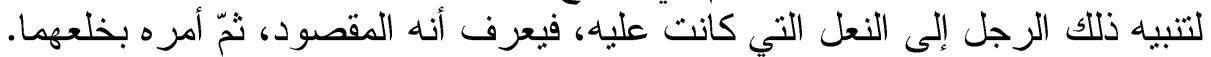

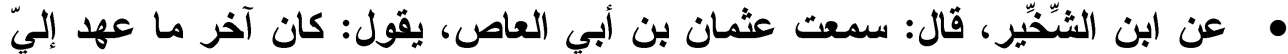

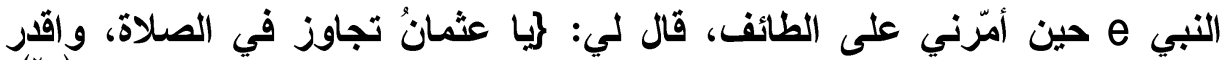

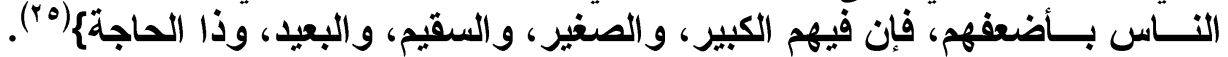

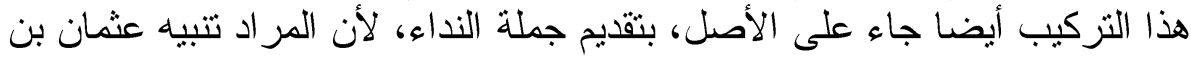

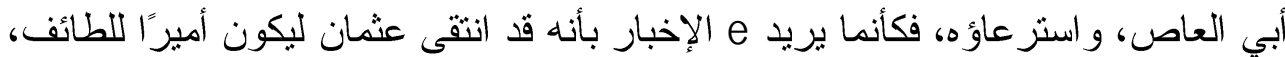

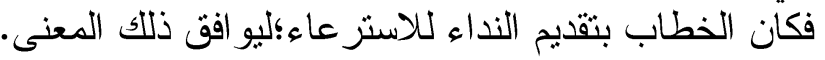

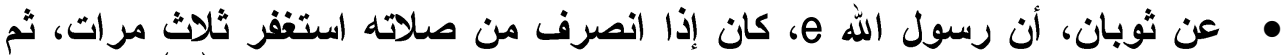

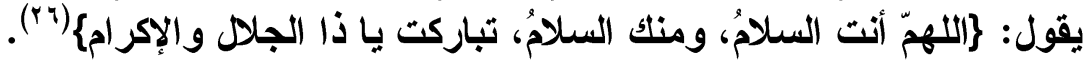

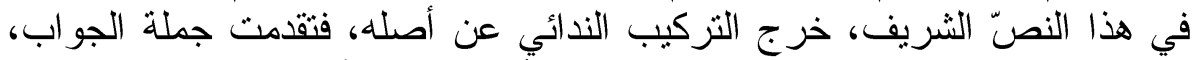
المبينة للغرض من النداء، على جملة النداء، إذ الآصل بمكن أن يكون: با ذأ ذا الجلال

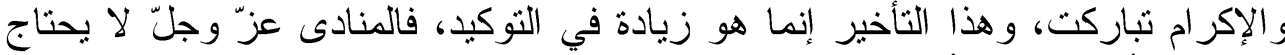

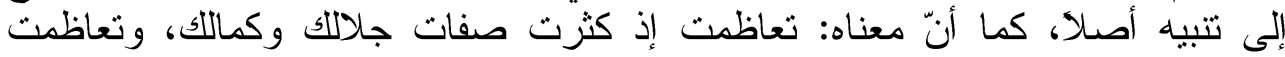

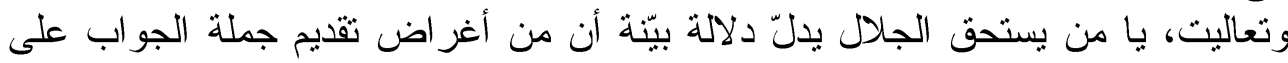

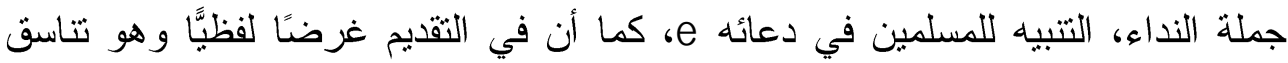

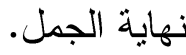

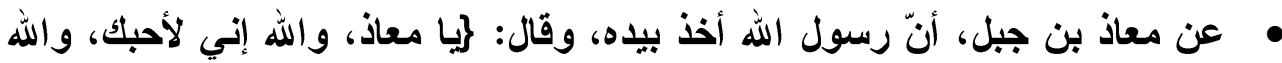

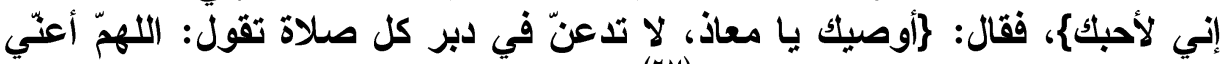

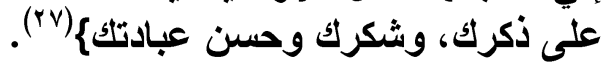

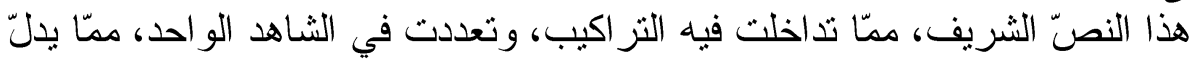

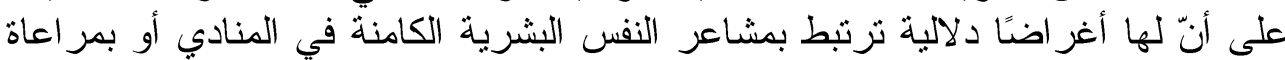

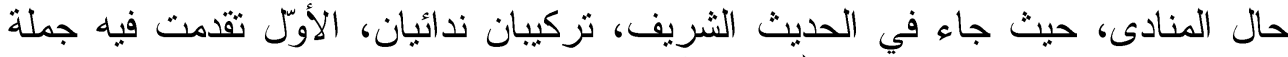

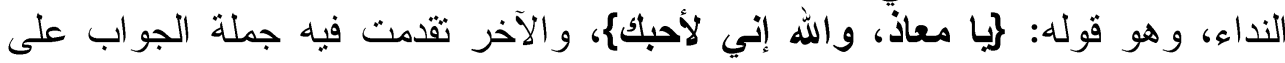

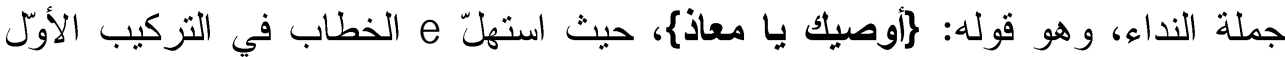

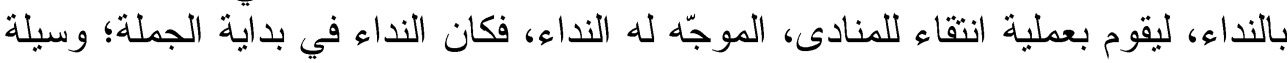

أما في التركيب الآخر، فقد كانت الغاية التخصيص، للتوكيد، لا للتنبيه؛ لأن استز عاء له.

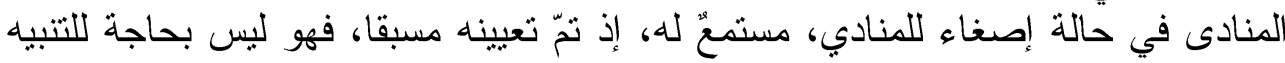

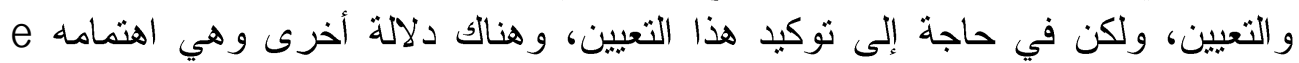

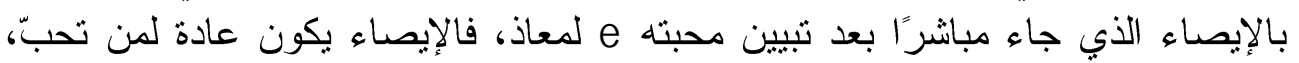




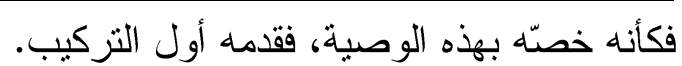

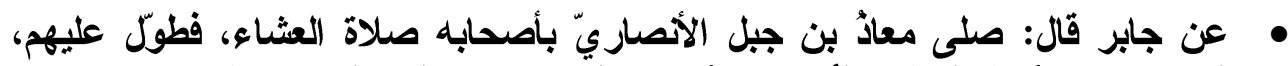

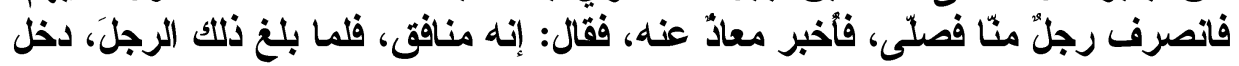

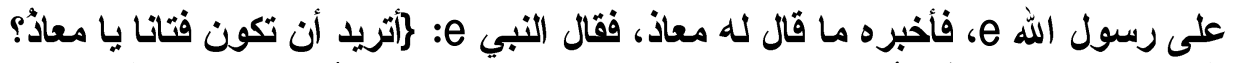

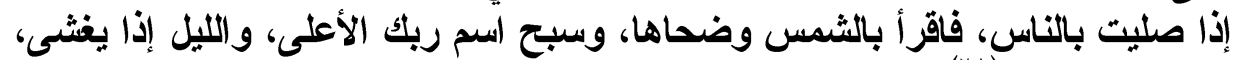

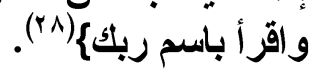

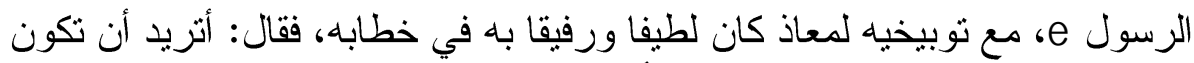

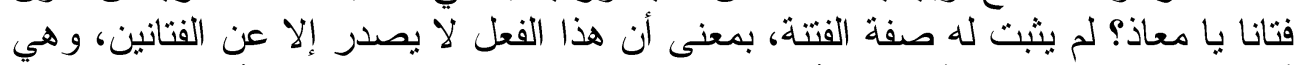

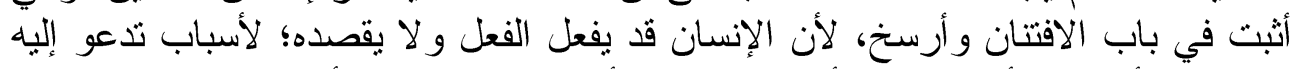

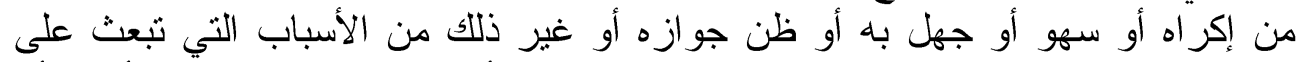

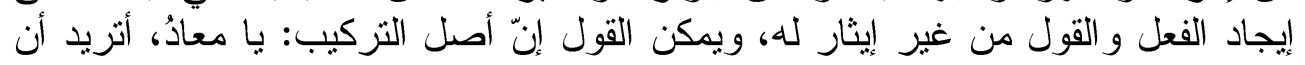

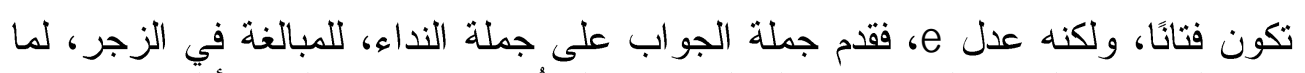

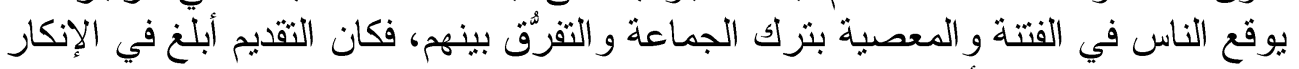

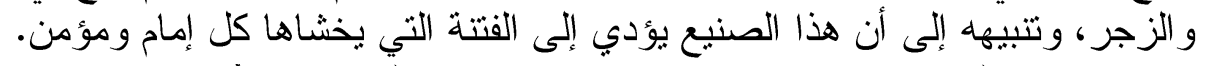

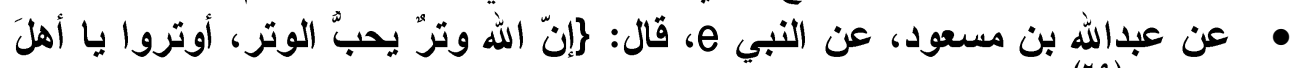

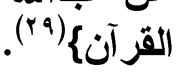

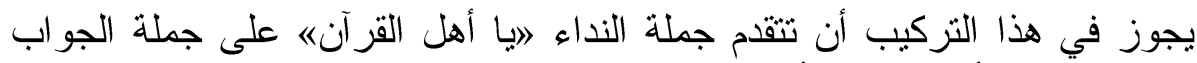

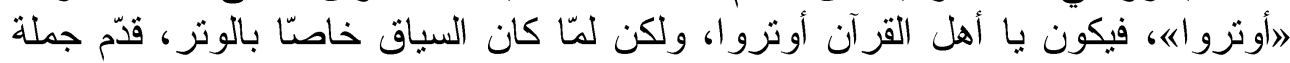

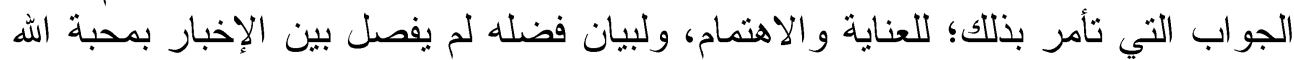

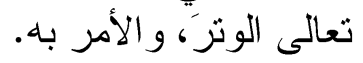

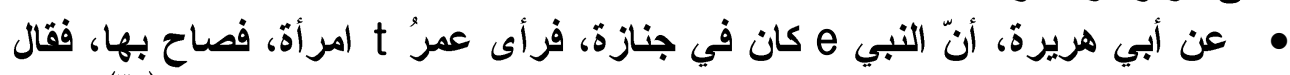

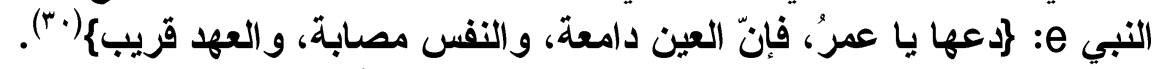

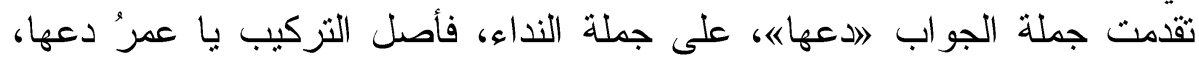

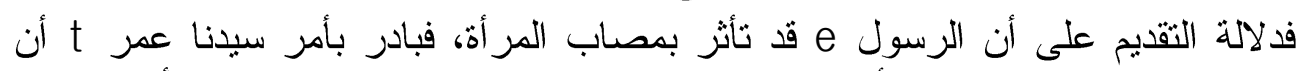

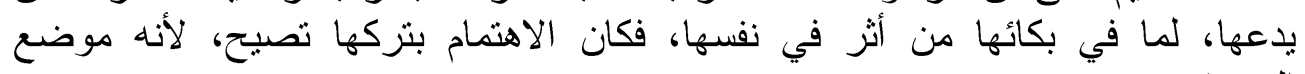
الحديث. • عن عائشة قالت: كان النبيّ e يتعوذ بهؤلاء الكلمات كأذهب البأسَ، ربَّ الناس،

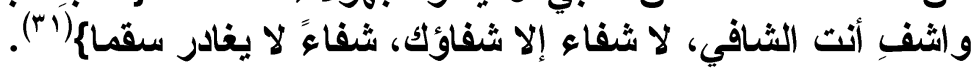

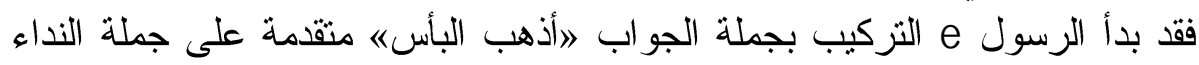

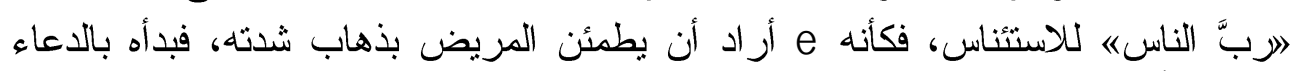

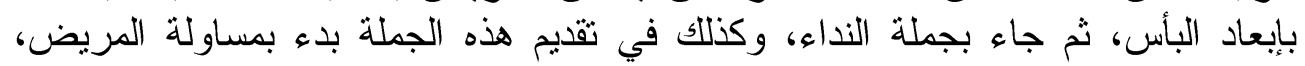
ومعاودته و استعجال الثفاء لهاء له.

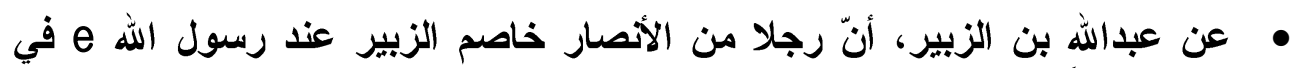

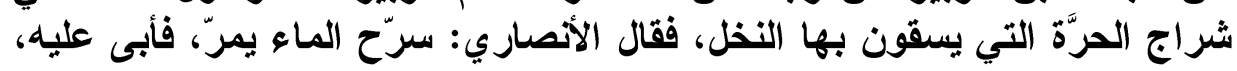

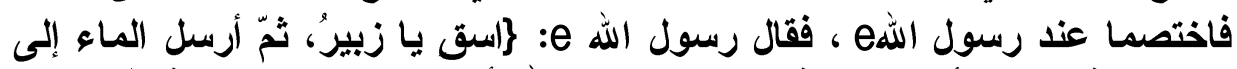

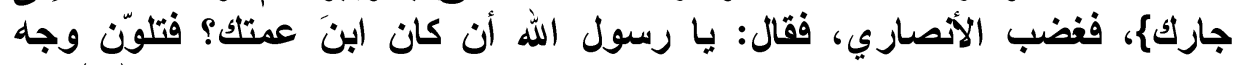

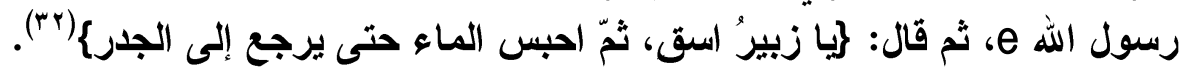


هذا الحديث ممّا تداخلت فيه التراكيب، وتتوّعت، فقد جاء فيه تركيبان ندائبان،

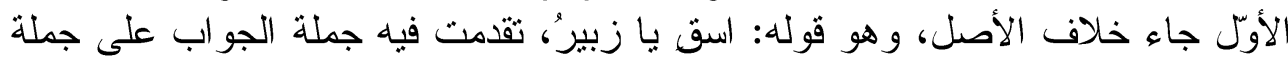

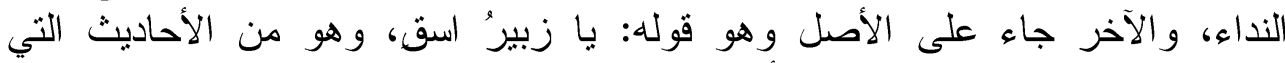

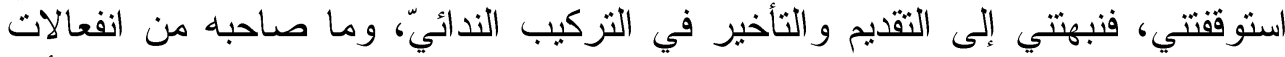

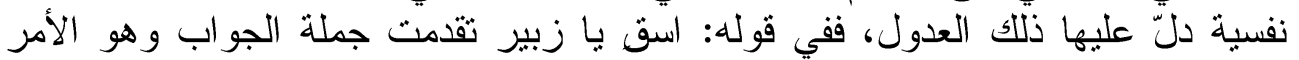

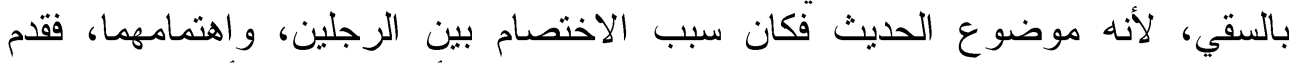

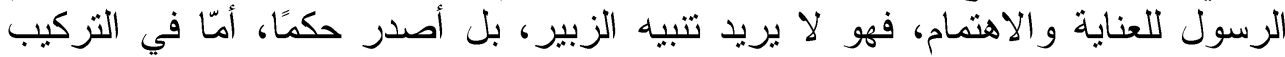

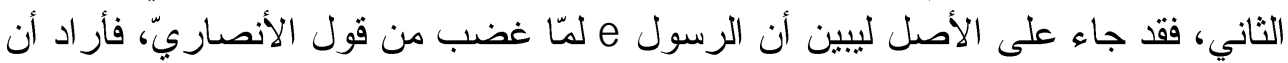

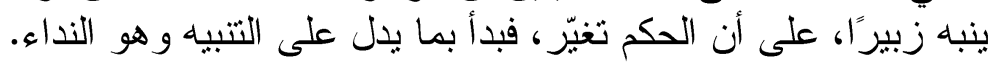

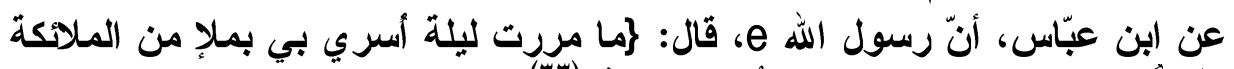

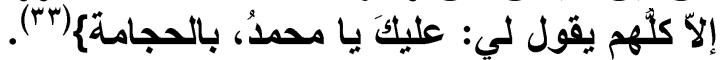

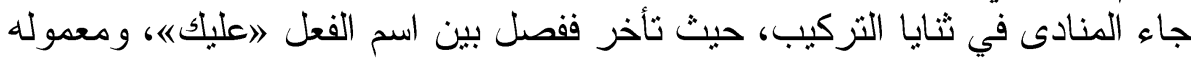

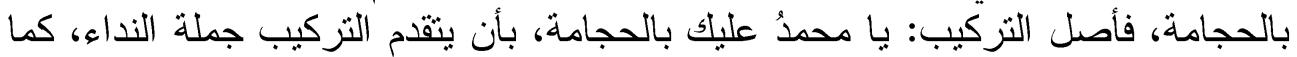

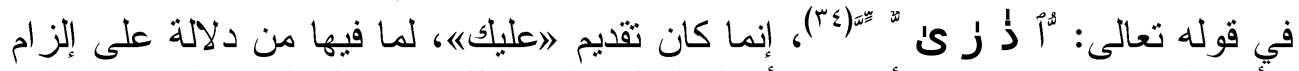
الأمر إلزاما مؤكدا، ففائدة أسماء الأفعال الدالة على الذه الطلب هي المبالغة و التوكيد، فكلمة

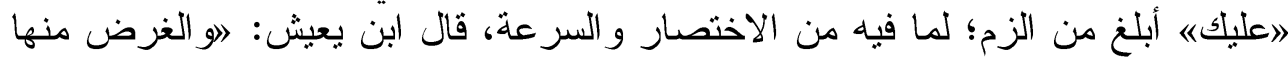

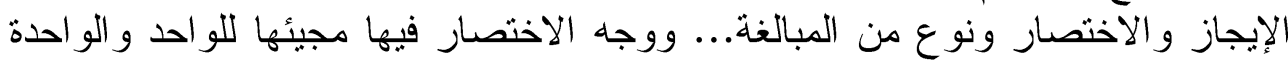

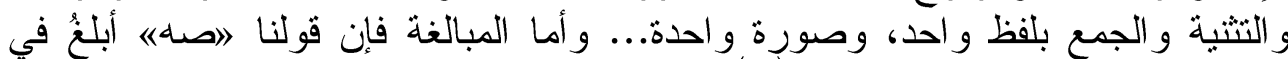

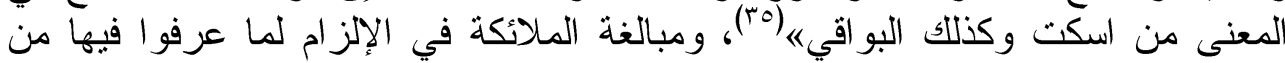

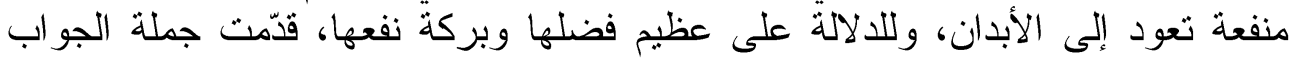

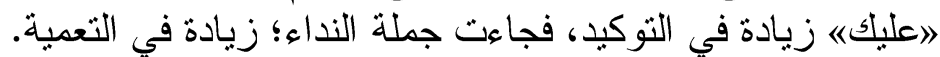

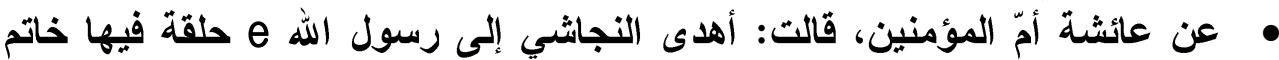

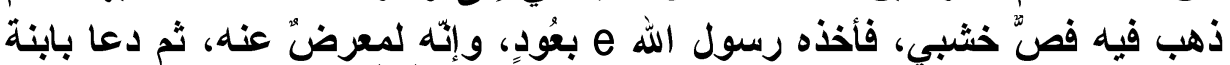

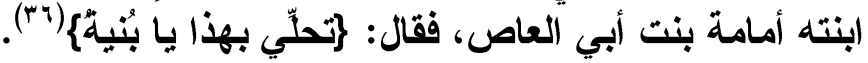

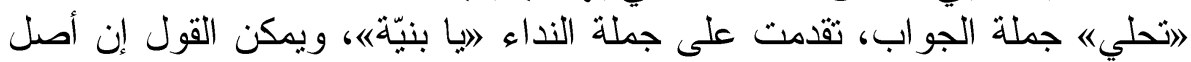
التركيب: يا بنيّة تحلّي بهذا، إنما قدّم ليدل من بداية الحديث على أن هذا حلية، تستعله إنها

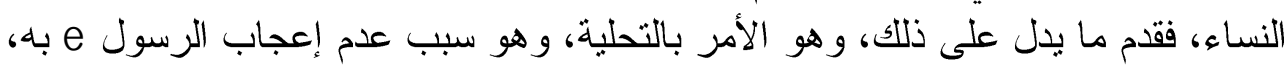

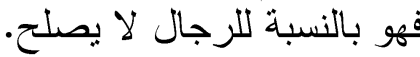

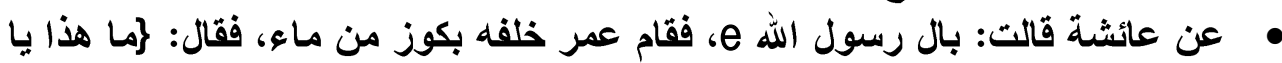

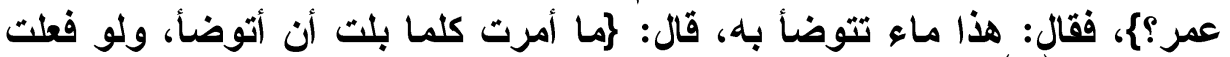

إنّ الأصل هو أن ثتصدر جملة النداء التزكيبَ، وهذا ما يستعطله e في أكثر

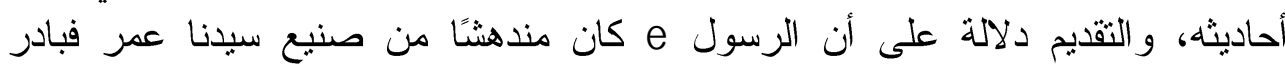

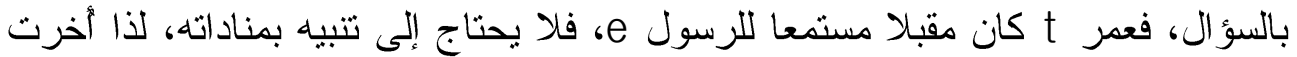

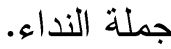

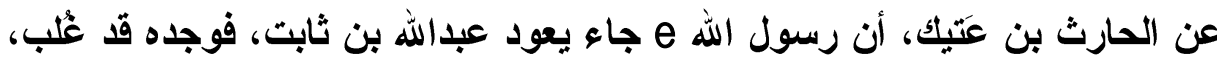

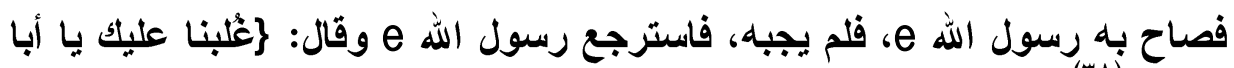
الربيع\{ (به) 


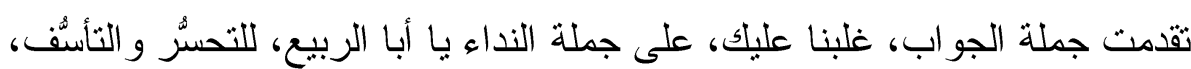

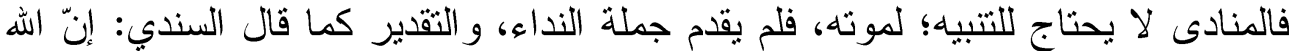

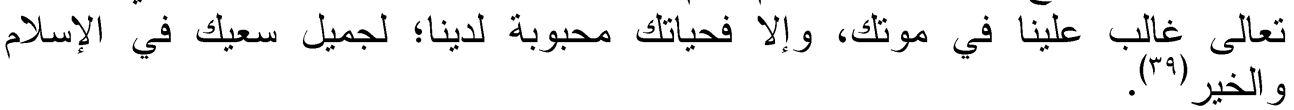

• عن أنس بن مالك،، أنّ رسول الله e، قال: [ندمع العين ويحزن القلب، ولانقول إلا

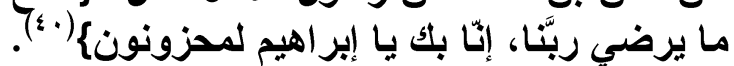

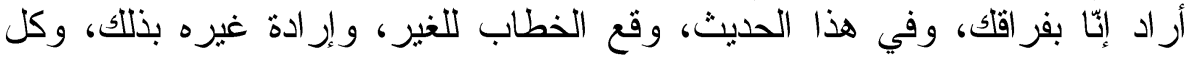

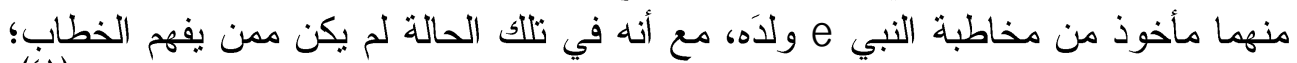

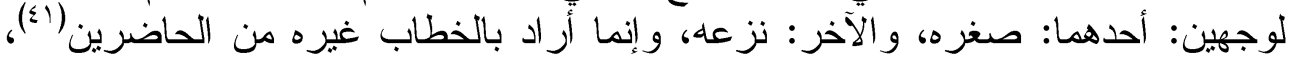

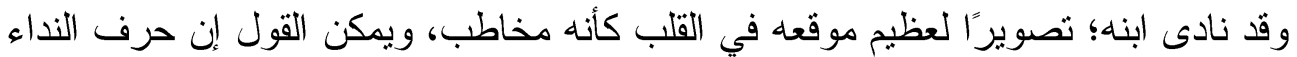

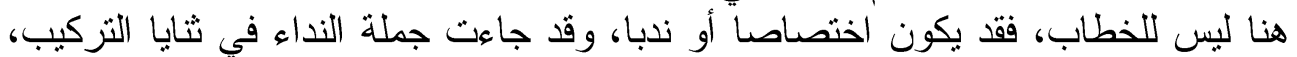
فقصلت مع متعلق خبر إنّ بين اسمها وخبرها، و أصل التركيب يمكن أن يكون: يا إبر اهيم

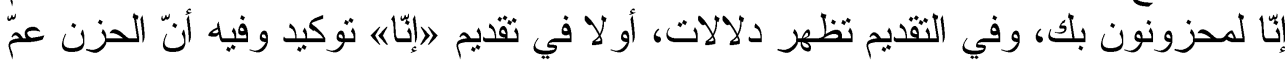

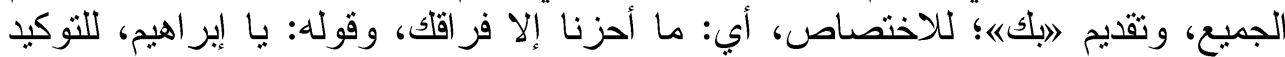

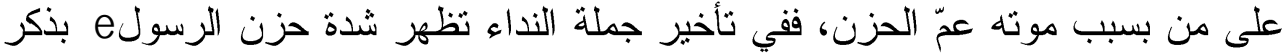

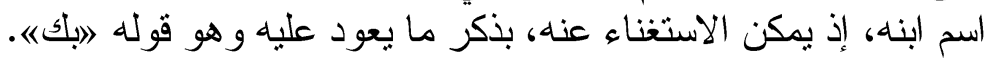

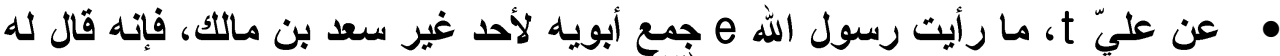

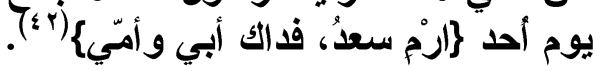

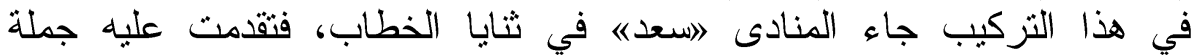
الجواب، وهو الأمر بالرمي لارجه، ويمكن أن يقال: إن أصل التركيب سعدُ ارم فدالك أبي التي

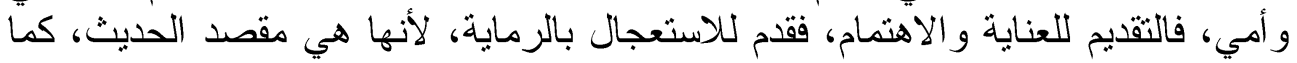

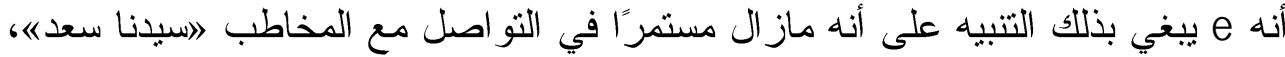

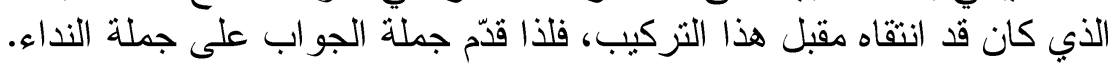

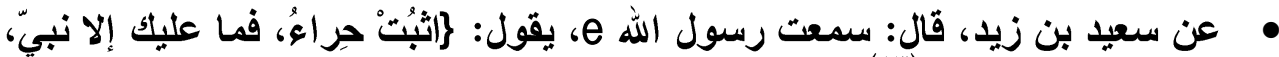

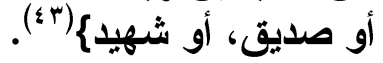

هنا الرسول e ينادي، مخاطبا جبل حراء وهو بمكة على ثلاثة أمبال، كان يتعبد

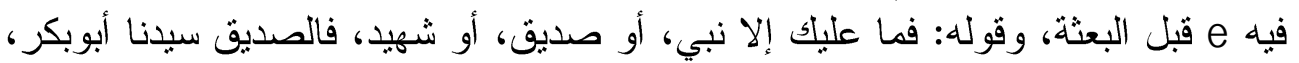

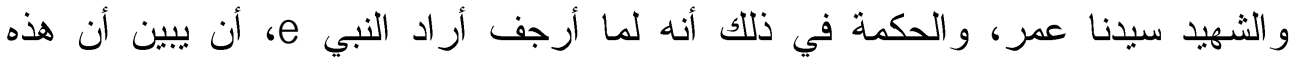
الرجفة ليست من جنس رجفة الجبل بقوم موسى عليه السلام لما حرفو ا الكلم، فتلك رجفة النة

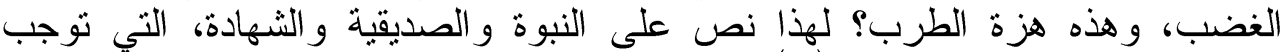

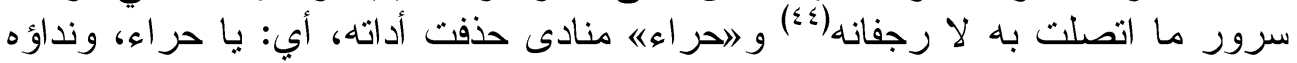

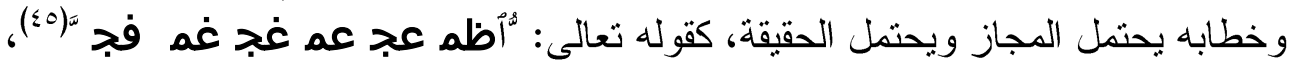

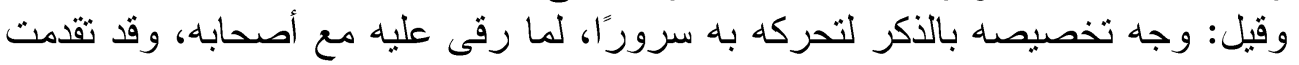

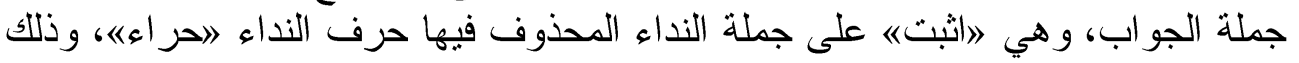

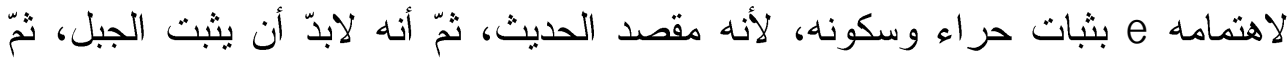

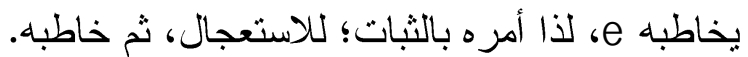




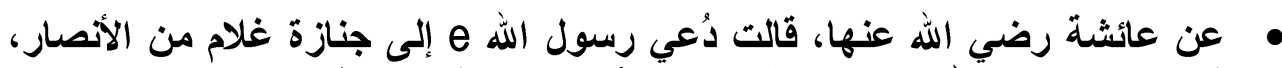

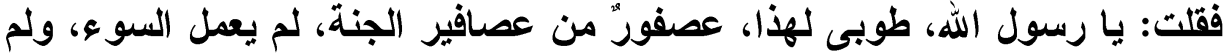

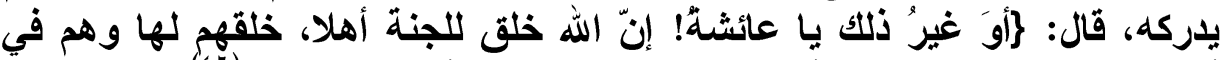

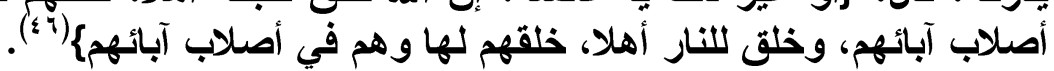

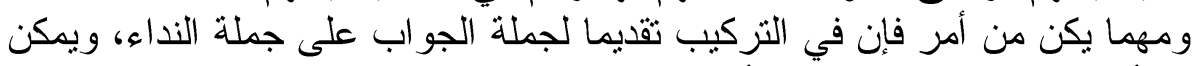

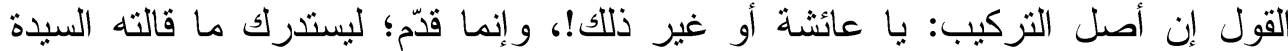

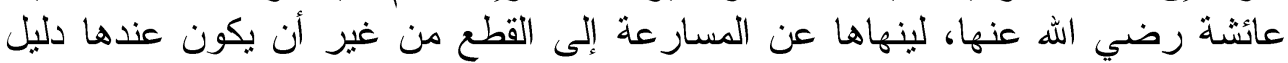
قاطع على ذللك، فاستدرك متعجبا؛ ليبين لها من بداية الكديث أنسان أو لاد المسلمين ليسوا

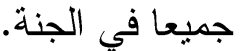

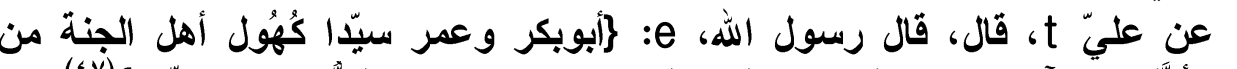

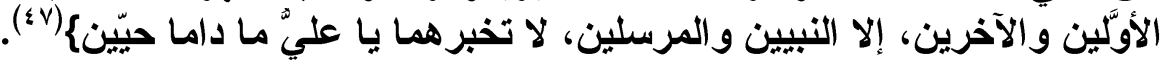

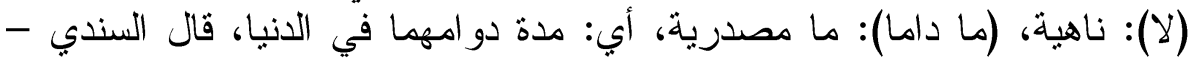

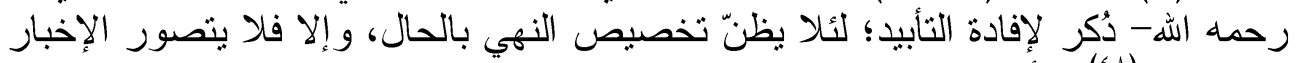

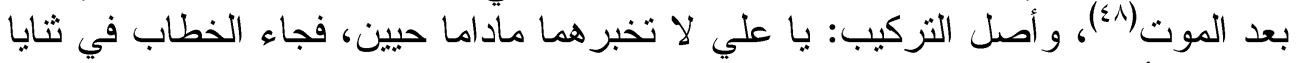

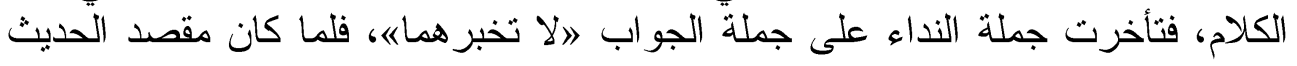

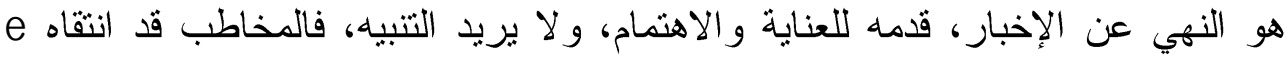

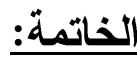

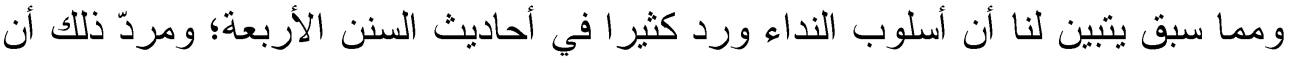

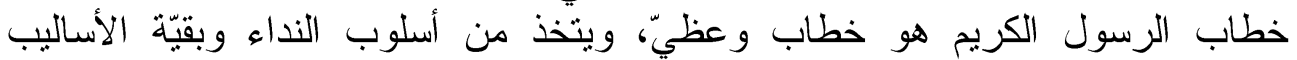

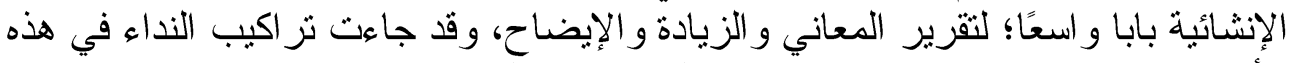

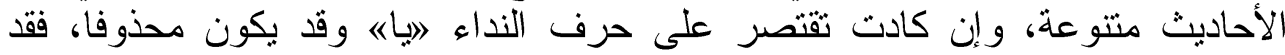

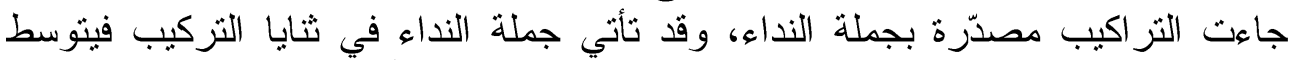

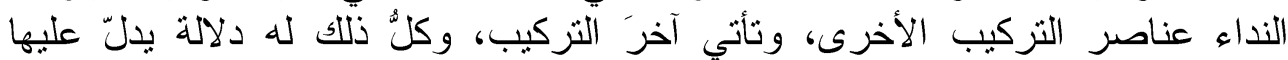

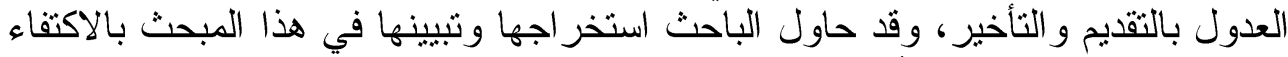

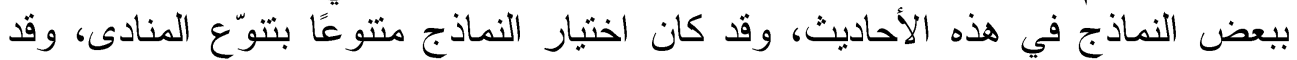

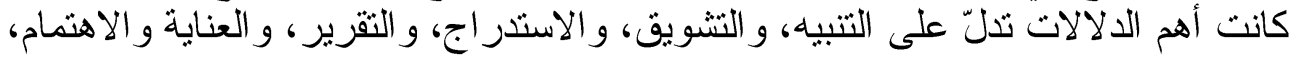

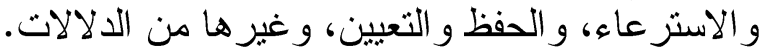




\section{Abstract}

"Submitting \& Delaying in Appealing Method"

\section{A Study of Synthetic Significance in the four Hadiths of the Sunnah}

By Essa otman mohmed

This research deals with the issue of the appeal, namely, "The Submission and delay between ths elements on which ti is based: "The letter of calling and the called one" and the command calling for it "The phrase of the appeal". The Research may Follow this issue through analysis and applying in the four Hadiths of the Sunnah indicating the most important indications that arise from submitting and delaying among the elements of calling composition, and it has an effect on the semantic meaning in the syntax of the sentence.

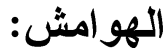

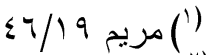

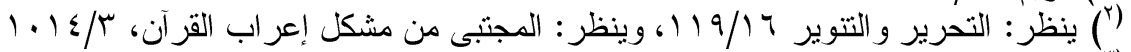

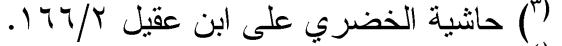

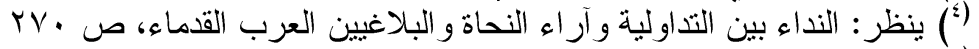

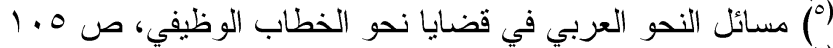

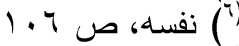

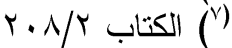

$$
\begin{aligned}
& r \cdot \lambda / r \text { نف }
\end{aligned}
$$

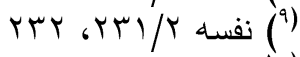

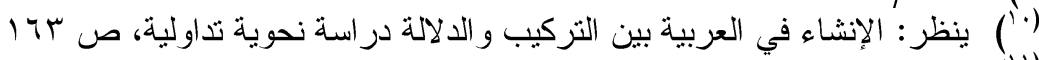

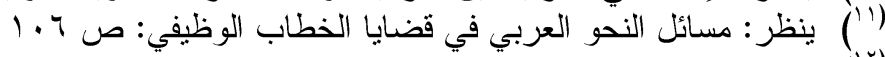

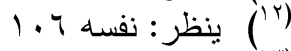

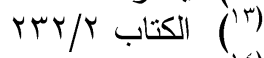

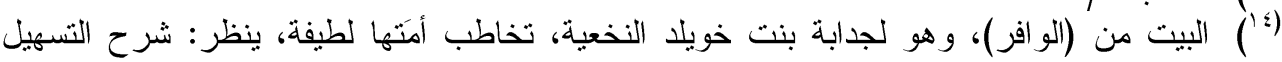

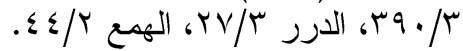

$$
\begin{aligned}
& \text { (ال) }
\end{aligned}
$$

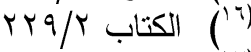

$$
\begin{aligned}
& \text { 01/0 شرح المفصل }
\end{aligned}
$$

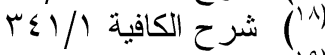

$$
\begin{aligned}
& \text { rV }
\end{aligned}
$$

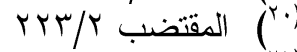

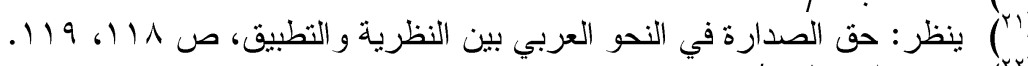

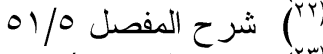

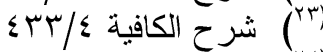

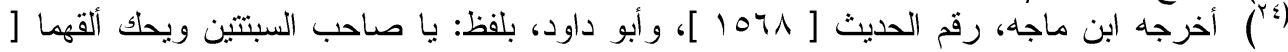

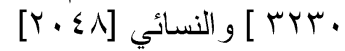

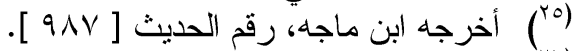

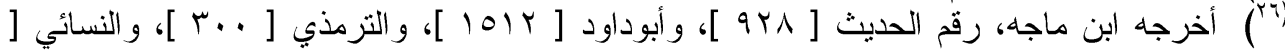

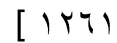

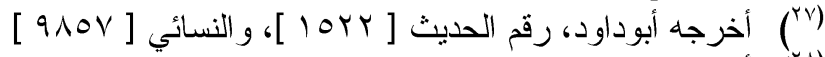

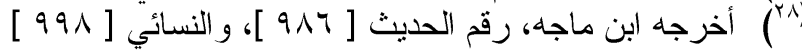




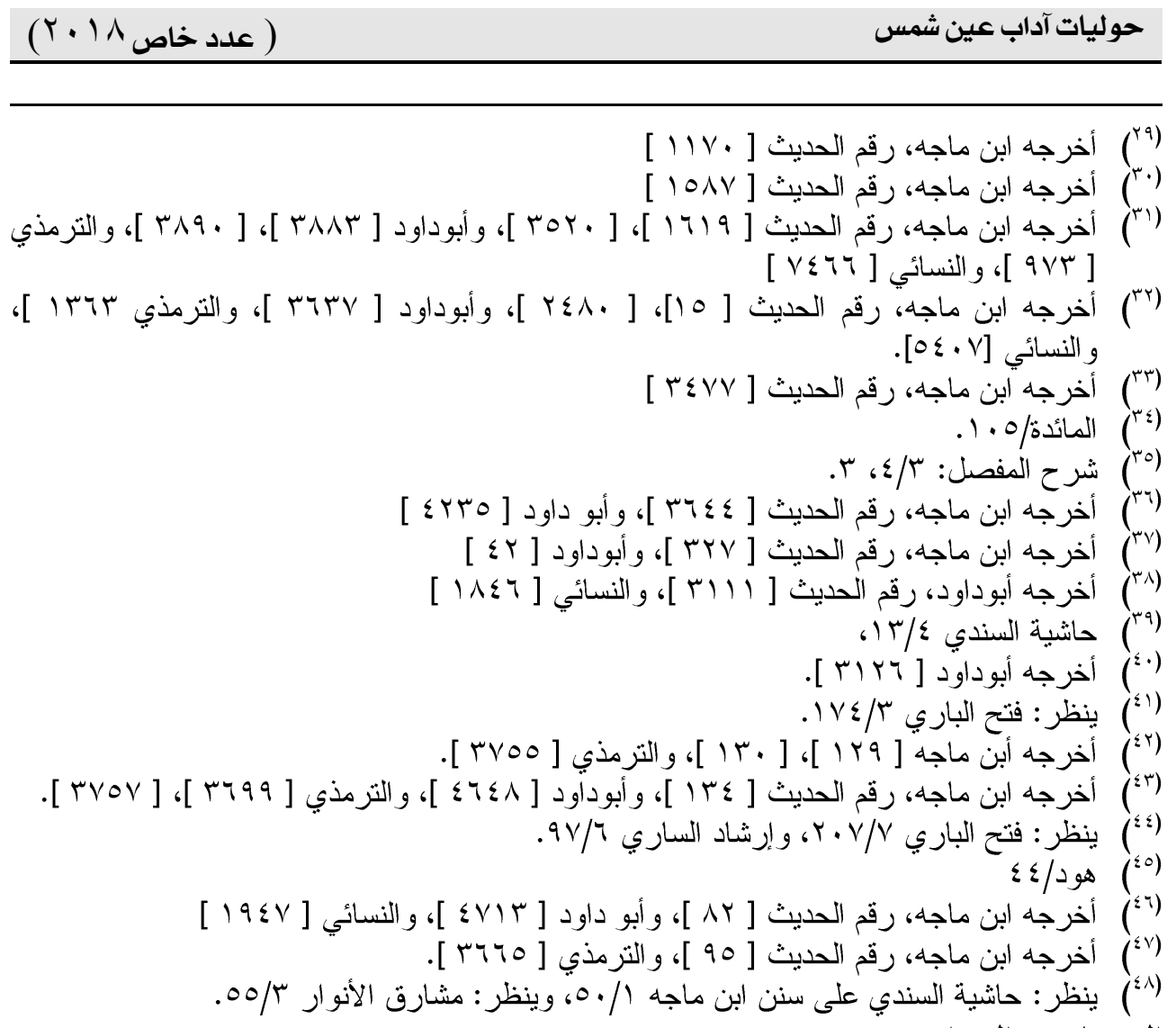

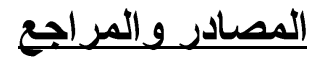

- إرشاد الساري لثرح صحيح البخاري، تأليف: أحمد بن محمد بن أبي بكر بن عبدالملائك القسطلاني

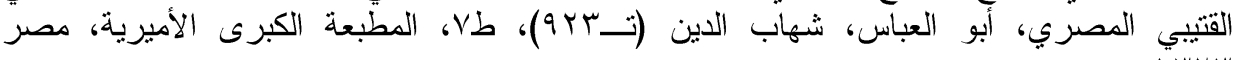

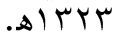

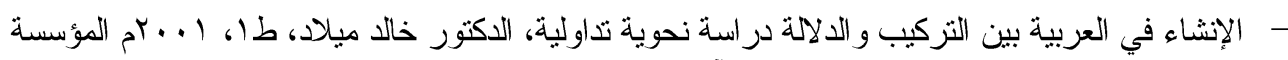

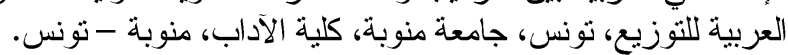

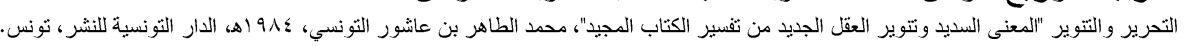

- - حاشية الخضري على شرح ابن عقيل على ألفية ابن مالك، دار الفكر للطباعة و النشر ، د.ت، ط، ن.

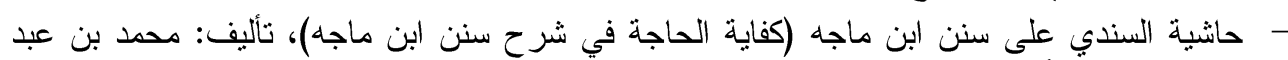

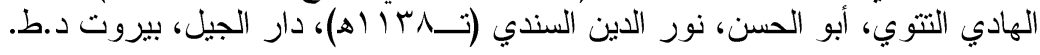

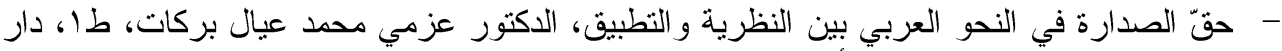

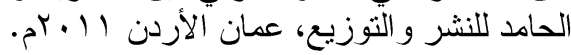

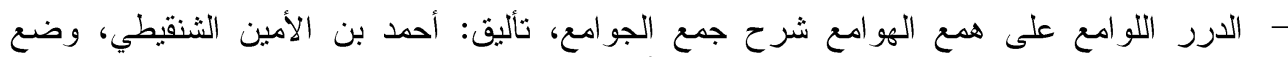

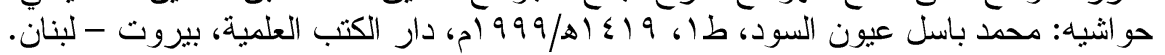

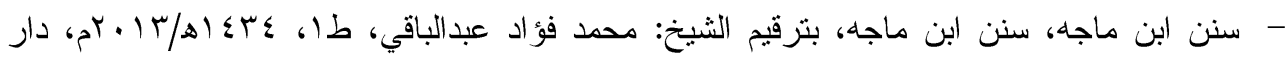

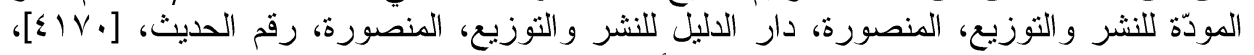

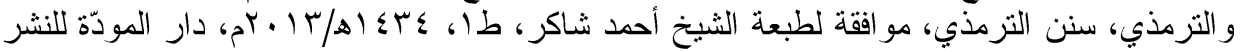
و التوزيع، المنصورة، دأر الدليل للنشر و التوزيع، المنيخ التصورة.

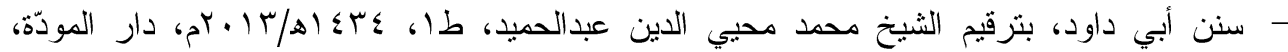
المنصورةة، دار الدليل، المنصورة.

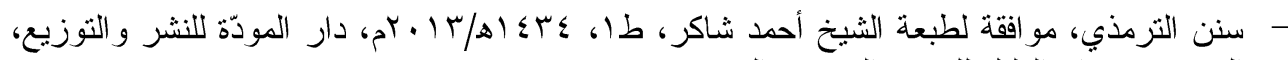
المنصورة، دار الدليل للنشر و التوزيع، المنصورة. 


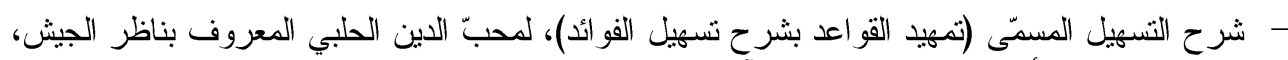

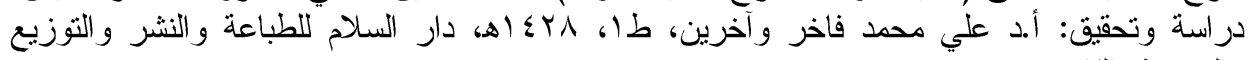
و التزرجمة، القاهرة - مصر . - شرح الرضي لكافية ابن الحاجب، للرضي الرضي الأستر اباذي، تحقيق: حسن بن محمد بن إبر اهيم الحفظي،

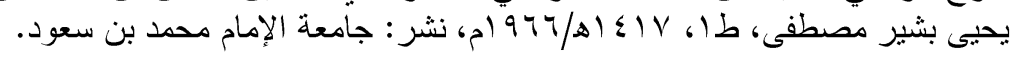

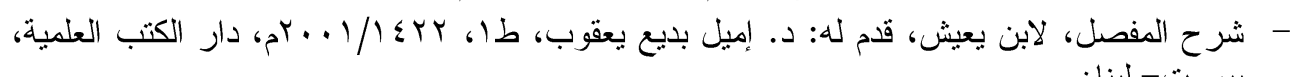
بيروت- لبنان.

- عمدة القارئ شر حسين صحيح البخاري، تأليف: أبو محمد محمود بن أحمد بن موسى بن أحمد بن حسين

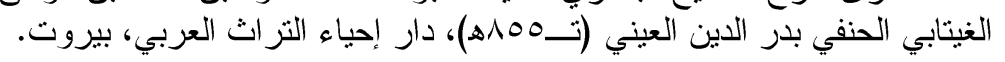

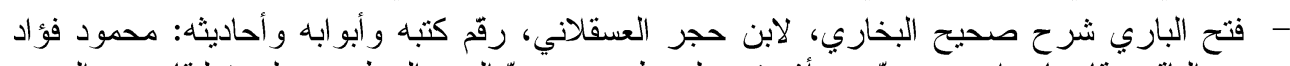

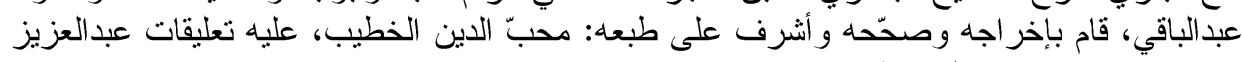

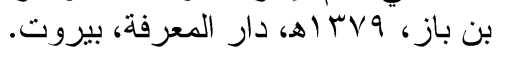

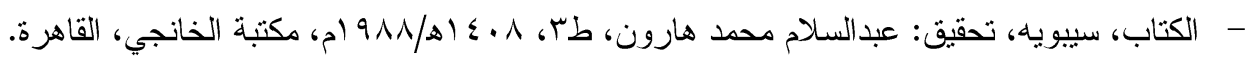

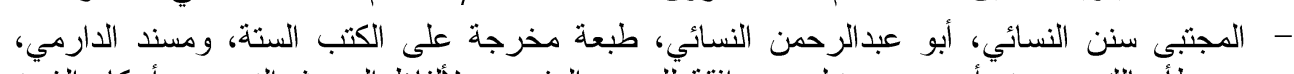

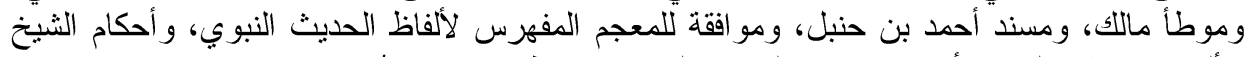

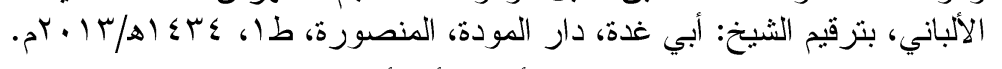

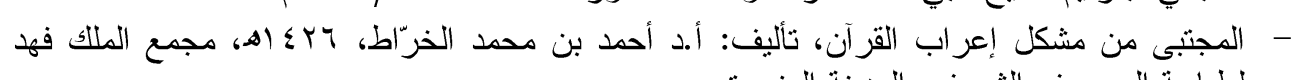

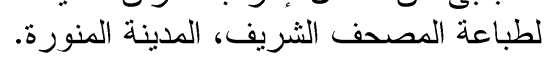
- مسائل النحو العربي في قضايا نحو الخطاب الوظيفي، د. أحمد المتوكل، طا، 9. ج. بع، دار الكتاب الجديد المتحدة.

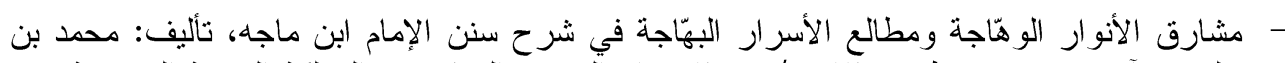

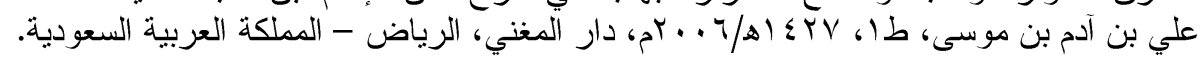

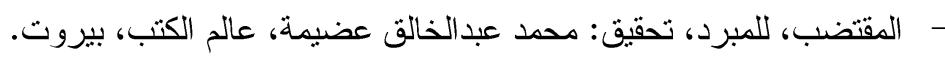

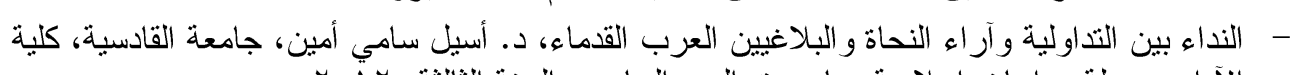

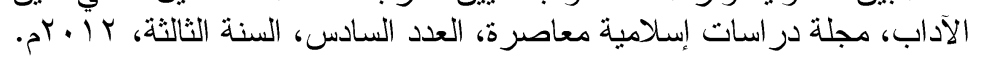

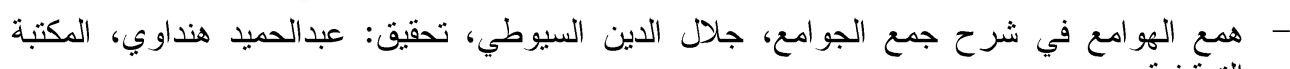
التوقيفية، مصر . 